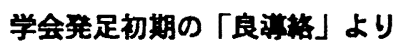

\title{
良導絡亡産婦人科疾患
}

東北大学医学部産婦人科学教室

（主任）九 嶋勝司教授

長谷川 直 義

1.はじめに

良導絡の理論と実際について、いわゆる科学 者なりと自負するるののなかには、これを自ら 追試することもなく、これは現代医学から遠く かけはなれたマヤカシあのである、という偏見 をいだいている人るあると思います。筆者らは 九鴄教授のご指導のると、多年にわたって、い わゆる婦人の機能性疾患についてくわしく研究 を続けてきたので、良導絡というすのに、少な からず興味をそそるものを感じました。これま での良導絡が説くところを調べてみますと、本 法による全良導絡の調整は、自律神経調整法に ほかならないといわれています。また、良導絡 によって女性の月経や妊娠や分婏などをいろい ろとコントロールすることの可能性すいわれて いますが、筆者らは、まず婦人の機能性疾患、 すなわち自律神経性婦人疾患に対して、本法を 試みてみようと考元、2、3 の実験を行ってみま した。その成䋶は以下にのべるうな興味のあ るあのでしたので、これらを中心に、良導絡の 現代医学における位置といったものに触れなが ら、のべてみたいと思います。

\section{2. 機能性媂人科疾急と自律神蛙系}

筆者らが良導絡に注目したのは、本法が自律 神経系の調整に関係しているといわれているか らだといいましたが、たしかに自律神経調整法 という言葉は、筆者らの注意を意くすのだった のでありあす。と申しますのは、女性は男性に 比して自律神経系が不安定なのが特徴の一つで あります。従って、婦人の自律神経性疾患は、 頻度も多いわけでありますが、この疾患の本態 が理解されないために、今日なお、誤った診断
や侾果のあがらない治療法がおこなわているの が現状なのです。そこで、筆者らは「その発症 に自律神経系が重要な役割を演じているがこと き疾患を自律神経性疾患とよぶ」と定義したの です。この疾患の代表的なるのに婦人の自律神 経 (失調) 症があります。

古来、本邦で俗間にいわれてきた「血の道」 という病気も、本疾患に含まれるものです。

自律神経症は婦人科外来では、非常に多くみ られる疾患で、その症状を示したものが第 1 表 です。これは自律神経症患者 300 例の症状数を

\section{第 1 表}

自律神経症状の頻度

\begin{tabular}{|c|c|c|c|c|c|}
\hline & 定 & 例数 & & 状 & 例数 \\
\hline \multirow{6}{*}{ (1) } & 热 & 127 & \multirow{7}{*}{ (4) } & 湩 & 156 \\
\hline & 椧 之 性 & 150 & & 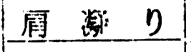 & 169 \\
\hline & ノホセ & 145 & & 関 節 痛 & 52 \\
\hline & 心悸元進 & 169 & & 哺 & $\underline{3}$ \\
\hline & 浱 & 44 & & 腓_㘉畄 & 42 \\
\hline & 遅 & 2 & & 脊椎演 & 40 \\
\hline \multirow{10}{*}{ (2) } & 頭 & 203 & & 坐咼捕 & 0 \\
\hline & 睡 & 154 & \multirow{3}{*}{ (5) } & 発开元進 & 81 \\
\hline & 不 & 155 & & 口内乾燥感 & 25 \\
\hline & 耳 鳴 & 88 & & 唾湤分速増加! & 2 \\
\hline & 閔 光 視 & 8 & \multirow{2}{*}{ (6) } & 㥧 展 & 70 \\
\hline & 医 迫 & 40 & & 排展捅 & 7 \\
\hline & 恐 怖 感 & 62 & \multirow{5}{*}{ (7) } & 心 & 80 \\
\hline & 咖憶力不良 & 5 & & i: ! & 3 \\
\hline & 判断力不良 & 4 & & 食烝不振 & 106 \\
\hline & 焦燥 感 & 35 & & 秘 & 69 \\
\hline \multirow{4}{*}{ (3) } & シビレ威 & 133 & & 逮 & 21 \\
\hline & 知觉過䑤 & 12 & \multirow{3}{*}{ (8) } & 退労 & 203 \\
\hline & 知觉鐩麻 & 24 & & 复 & 48 \\
\hline & 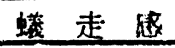 & 31 & & 不 熙 症 & 28 \\
\hline
\end{tabular}


示したすのですが、これらの症状と良学絡症候 群として示された症状とが大変、似ていること に注意していただきたいと思います。ここに、 (1)は血管運動神経系障害様症状、(2)は精神神経 系障害様症状、(3)は知覚系障害様症状、(4)は運 動器官系障害様症状、(5)は皮店分泌系障害様症 状、(6)は泌尿器系障害様症状、(7)は消化器系障 害様症状、8はその他の症状と大別されます。

比较的に発生頻度の高い症状としては、頭 痛、疲労感、肩凝り、心悸穴進、腰痛、不眠、 めまい、冷え症、逆上（ノボセ）、しびれ感、熱 感、食欲不振などをあげることができまます。 従って良導絡の不問診というすのが、これらの 症状を適確にとらえることができれば、自律神 経症の臨床に大いに役立つわけであります。

ここに、自律神経症の各症状は、すべて自覚 的症状でありますが、以下のような特徴を持っ ています。(1)日により、時により変動しやすく、 部位的にも移動する傾向が強い。(2)感情状態に よって影豐を受けやすい。(3)一般に二つ以上の 自律神経症状を伴っている。(4)一般に自律神経 機能が不安定である…...などであります。これ らの症状は、更年期婦人によくみられる「いわ ゆる更年期障害」の症状を思い出されれば、す ぐ理解いただけると思います。更年期障害す、 実は更年期に発症する自律神経（失調）症にほ かならないのです。

ところが、これらの症状は、ひとり更年期に のみ、みられるものではなく婦人のあらゆる年 令層に認められるすのです。第 2 表には発現時 期別にわけて、その頻度を示してみました。こ こに、心因性 (b) とあるのは、婦人の精神身体 症といわれる疾患に含められるるのですが、重 要なるのですから、後章にあらためて説明いた しましょう。

この表加ら、自律神経性（a）の婦人疾患とい うすのは、思春期にす、月経時、妊娠時、分婏 後、流産後、各種の婦人科手術後にす、また、 老年期にあ発症するすのだということがおかか りだと思います。

さて、このような症状は、どうして発症する のでしょうか。婦人自律神経症の本侦を理解し ておくことは、本症にたいする正しい診断や正
初 2 ?

\begin{tabular}{|c|c|c|c|c|c|c|c|c|c|c|}
\hline \multirow{3}{*}{ 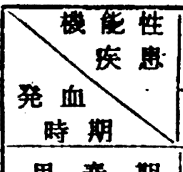 } & \multicolumn{2}{|c|}{ 息律 } & \multicolumn{2}{|c|}{ 整病 - } & \multicolumn{4}{|c|}{ 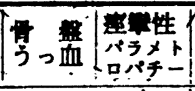 } & \multicolumn{2}{|c|}{ 膀腌絖 } \\
\hline & a & b & a & b & $\mathbf{a}$ & b & $a$ & b. & & b \\
\hline & 25 & 5 & 5 & 1 & 7 & 2 & & & & \\
\hline 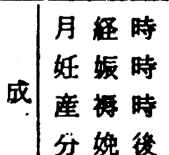 & $\left(\begin{array}{l}80 \\
16 \\
14 \\
23\end{array}\right)$ & $\begin{array}{r}10 \\
4 \\
6 \\
9\end{array}$ & $\begin{array}{l}2 \\
6 \\
2 \\
4\end{array}$ & 1 & 4 & 1 & 5 & 3 & 2 & 1 \\
\hline 流座啳 & 18 & 7 & 3 & 1 & 3 & 1 & 4 & 2 & 1 & 1 \\
\hline 熟人工流産後 & 17 & 11 & 8 & 3 & 8 & 4 & 8 & 5 & 8 & 4 \\
\hline 不妊手術啳 & 21 & 12 & 5 & 2 & 7 & 3 & 7 & 5 & 7 & 3 \\
\hline 去勢 後 & 28 & 6 & 1 & & & & 3 & 1 & 1 & \\
\hline 期子宫剔除後 & 16 & 8 & 4 & & 4 & 1 & 15 & 6 & 3 & 1 \\
\hline 中年 期 & 184 & 32 & 83 & & 65 & 15 & 21 & 10 & 10 & 2 \\
\hline その他 & 32 & 5 & 7 & & & • & & & & \\
\hline 更 年 期 & 174 & 20 & 14 & 2 & & & & & & \\
\hline 老 年 胡 & 28 & 5 & 6 & 1 & & & & & & \\
\hline 計 (例数) & 676 & 140 & 150 & 11 & 98 & 27 & 63 & 32 & 32 & 12 \\
\hline PS Dの傾度 & 20. & $7 \%$ & & $3 \%$ & & $5 \%$ & & & & \\
\hline
\end{tabular}

a：自律神経性， b ：心因性。

しい治療をおこなう上からす、大切なことであ ります。

婦人には月経・妊娠・分婏・産裤・閉経など があって、その内分泌環境はたえず、大きな変 動にさらされておりますが、この内分泌環境を 支配している内分泌膜器は下垂体であります。 ところが、最近の研究ではこの下垂体と間脳視 床下部とは機能的に一つの単位であって、性中 枢は視床下部にあるとされています。その間脳 視床下部には、また自律神経中枢が存在してい ます。従って、内分泌の変動は間脳自律神経中 枢にも容易に影慗をおよばし、この部の失調を おこして、そのためにいろいろな自律神経系の 症状を発生せしめるのだと理解することができ ます。

同じような原因でおこるものには、婦人の自 律神経症のみならず、第 2 表に示したように、 自律神経性にくる婦人の腰痛症や下腹痛、それ から子宮うっ血症や痤等性パラメトロパチーそ の他があり、これらは腰痛、下腹痛、下腹部重 王感、下腹部钐満感などを主症状とし、これに いくつかの自律神経症状（第 1 表）を伴ってお ります。また、いわゆる膀胱神経症も自律神経 
性におきるものがあります。本症は排尿痛、頻 尿、残尿感を主症状としますが、良学絡症候群 の中にしめされている小便異常というるのの一 部に相当するすのかどうか、これまた検討の必 要があります。

以上のように、産婦人科疾患のうちで頻度の 高い機能性疾患は、実は自律神経性疾患にほか ならず、この疾患は自律神経系が大いに関係し ているすのであって間脳自律神経中枢の失調が 原因で発現するるのであります。従って、ここ に実際の臨床では、患者の自律神経機能がどの ようであるかを検查することが必要となってく ろわけであります。筆者らが、良臫絡を取りあ げたのあ、ノイロメーターを用いることによっ て、果して自律神経機能の状態を窥知すること ができるかどうか、をまず、検討するためだっ たのです。

\section{3. 自律神経權能検查法の实意}

婦人の機能性疾患を扱う上で、自律神経機能 の状態を知ることが、極めて重要であることは 申しのべましたから、おわかりになったことと おすいます。ところが、自律神経系の緊張状態 を簡単に知る、ということになりますと、これ は中々むずかしいことなのです。そのため、臨 床医がどんなに困っているかを少し説明せねば なりません。

（1）自律神経緊張状隼についての考え方

一その歴史的考察一

自律神経系の失調とか、不安定性とか、腎張 状热などによって症状が現われるということ が、よくいわれるわけですが、こうした状態は 一体、どういうことなのか……ということがま ず問題になってまいります。この問題に関し て、1910年に Eppinger \& Hess は、くわしい 薬物試験をおこなった結果、交感神経系と副交 感神経系は、互いに拮抗的に倾いているもので あって、この二つの緊張度の代数和が自律神経 㗨張度であると考えました。そしてアドレナリ ンに反応が敏感であって、ピロカルピンやアト ロピンに敏感でないものをジンパチコトニーと よび、これと反対にアドレナリンは敏感ではな いがピロカルピンやアトロピンに反応の敏感な
あのをワゴトニーと名づけました。しかし、こ の薬物試験そのものに疑いをはさむものも現わ れました。一方これとは別に、1928 年に Bergmann は、交感神経系之副交感神経系は互い に独立して反応するすのであって、自律神経不 安定症候とよぶのがよいと提唱しました。

ところが、1955 年になりますと、Hoff とか Wenger とかいった学者は Bergmannの考え は本質を究めるすのではないとして Eppinger \& Hess の立場に立って、るし薬物試験でおこ なうことにいろいろと批判があるなら、桼物以 外の方法で固体の自律神経緊張状態をみればよ いではないか、と考えました。

これより少し前の 1947 年に、W. R. Hess が、 また 1949 年には黒津教授らは、間脳視床下部 に自律神経中枢のあることを発見し、中枢によ る調整というるのがあることを指摘いたしまし た。こうなってまいりますと、どうしても中枢 というすのを無視するわけにはまいりません。 そうこうして、1957 年に Gellhorn がメコリー ルーノルアドレナリン試験という薬物試験によ る自律神経機能楧查法を考えだしたのですが、 これは神経生理学的な裏づけをされたすのとし てもてはやされたのでした。この発展の経過を 表示したすのが第 3 表であります。しかしこれ で問題がすべて解決したわけではないのです。

（2）自律神経㗨張状態に関する最近の知見 最近、この方面の研究が進歩するにつれて、 自律神経㹂張状態というものにたいする考え方 あ、より複雑になってきました。第一は中枢の 問題であります。間脸視床下部にはたしかに自 律神経中枢が存在しますが、更にその上位の大 脳辺緑系と呼ばれる部分は、特定の自律神経機 能に対して特異的な作用をすつということが最 近の研究でわかってきたのです。更にその上位 の新皮質にす、自律神経に関係する部位すいく つか発見されております。良導絡と非常に関係 の深い龟流皮游反射 (GSR) を用いての実験に よりますと、新白質一大脳讱緑系一間脳視床下 部の経絡のほかに、脳幹網様体す大いに関係を るっているといわれています。このように中枢 の問題だけをみてもなかなか複雑であるようで す。第 2 は末梢性の自律神経調節機棈の問題で 


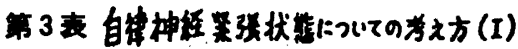

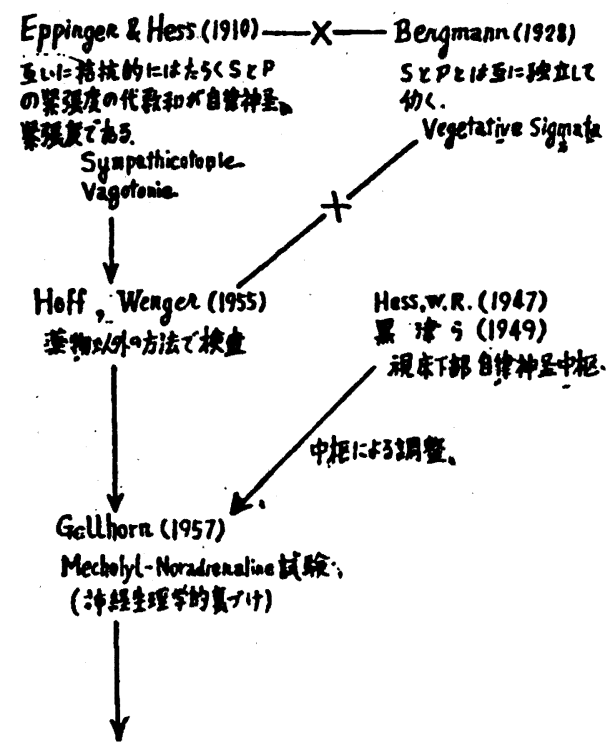

す。自律神経系は単に中枢だけでなく、頝動脈 洞とか大動脈反射とかいった末梢の調節機構も 関係していることを忘れることができません。 このようなことが最近、問題となっているわけ であります。第 1 図にはこの辺の問題点を図示 しておきました。

（3）自律神経機能検查法についての考え方 以上のように未解決な問題はないわけではあ りませんが、だからといって手をこまねいてボ ンャリしているわけにはまいりません。そこで 今日、おこなわれている自律神経機能検查法と いうすのをすう一度、ふり返ってみてみる必要 があります。これは、大体、方法論の上から 2 つに分けることができるようです。その 1 は静 的検查法ともいえるすので、安静時において、 中枢からのインパルスによって規定されている ある特定の組織や器官の機能を钼察する方法で す。その 2 は動的検查法とすいえるるので、何 らかの負荷をかけてみるのです。すなわち神経 性インパルス、または組織や器官の機能を指標 として、これに一定の負荷をかけて、それにあ とずく反応の大きさを測定する方法です。たと えばアドレナリンを注射して脈博数の增加をみ るのあ後者に属します。ノイロメーターによる 良導絡テストは、12 ボルトの電流 (=負荷)を

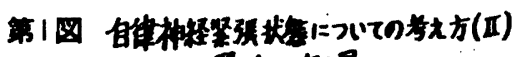
最近の知見

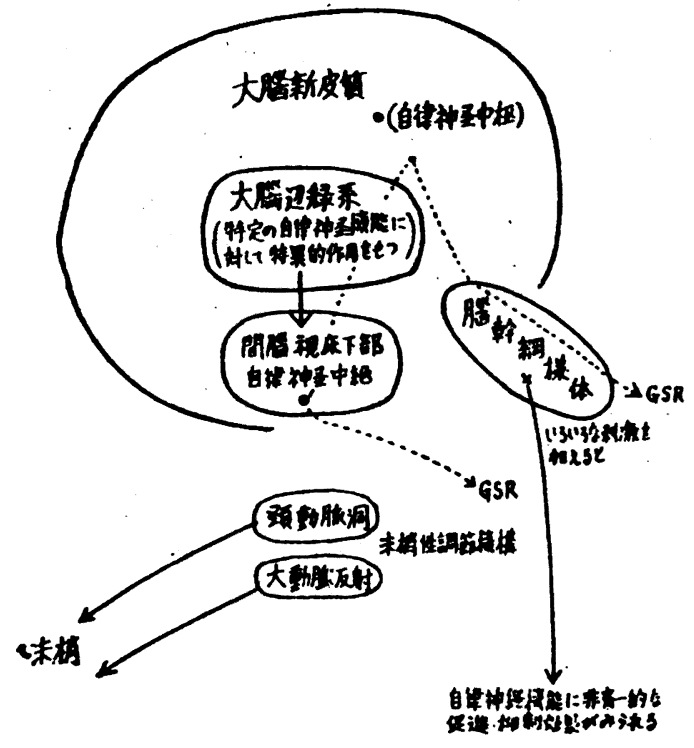

かけて、これによる皮府の通電抵抗（=反応の 大いさ）を湘定するすのですから、これは後者 に属する方法であると言えましょう。

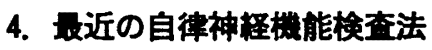

前回、のべたような原理にしたがって、おこ なわれている最近の検查法を眺める前に、歴史 的にす、また現在の状況からす、好んで用いら れている薬物試験にふれておく必要がありま す。

(A) 薬物試験に対する批判

今日、どの教科書をひらいてみても、自律神 経機能検查法として、まずあげられているすの に、アドレナリン試験、アセチルコリン試験、 ピロカルピン試験、アトロピン試験などがあり ます。そして最近では、.1948 年に Funkenstein らによって発表されたノルアドレナリン試薬や メコリール試験がよく用いられております。こ れはノルアドレナリンを注射しますと、末梢血 管が収縮して血圧が上昇し、またメコリールを 注射しますと、末梢血管が拡張して血圧が下降 しますが、このような末梢性の血圧変動の程度 から判定をくだすわけであります。この際、末 梢の血圧変動を規定しているものは、ノリアド レナリンにたいしては視床下部の交感神経中 
权、またメコリールにたいしては視床下部の副 交感神経中枢の調節作用であります。こうして 薬物を負荷して、中枢の調節機能の具合をみて いろわけでありますが、実は血圧変動に影整を およぼす要素は、単に中枢だけではなかったの であります。といいますのは、中枢のほかに少 くとも3つの要素が関係していることを見逃し てはならないというのです。

その 1 つは末梢性の頚動脈洞や大動脈弓など の反射性血圧調節であり、したがって、これら の圧感受器官の性能が問題となるわけです。そ の 2 は末梢血管の薬物にたいする感受性の問題 があります。その 3 は、さきにす触れました脳 幹網様体の機能の問題であります。このような 問題が関係してまいりまして、甲状腺ホルモン とか副腎皮質ホルモンとかの分泌に異常をきた しているものや老年者や糖尿病で血管に器質的 変化を伴うあのにたいするこれら薬物試験によ る自律神経機能検查はあてにならないという批 判がおきてくるのであります。

そこで今日では、単に菓物試験だけでなく、 いろいろな自律神経機能検査法というすのが考 察され、試用されているのです。良覚絡テスト が真にすぐれた自律神経機能検查法であるため には、他の検查法と比较してどの点で正にすぐ れており、るし限界といったすがあるとすれ ば、それはどこまでか……といったことを検討 して、はじめてその真価を発揮することができ るものだと思います。そこで、筆者は現在、各 方面でおこなわれている方法というすのを一 応、知っておく必要があると思うのです。

（B）現在おこなわれている検查法

自律神経機能にかんする研究は、基礎的研究 之臨床とが㗨密に結びついておこなわれていな いために、したがってその検查法となります と、実際の臨床に用いて简単で、かつ適確なよ い方法がないのが現状のようです。それだけ に、この方面の検查には非常に沢山の方法が、 各人各様におこなわれております。第 4 表から 第 7 表までは、これらの検查法を大別して、報 告者とその要点を附記したものです。

で、結局のところ、いろいろな方法がありま すが、薬物試験は前にのべた通りであって、あ
とは自律神経によって支記されている皮店機能 とか、循環器機能とか、その他の身体機能の反 応を指標として、個体のいわゆる自律神経緊張 状隼ないしは自律神経不平衔度を調へるゅき方 がとられています。それに自律神経機能と関係 のありそうな項目を湘定して、これを数学的に 処理する Wenger 法や、最近、自律神経機能と 関係があるといわれているカテコールアミンを 定量する方法などがあるわけです。一つ一つに ついてのくわしい説明は、この論文の主旨から はずれますから、省略しますが、やはり検査法 はできるだけ簡単に、誰にもできて、しかも数 量的に正確にとらえられるすのでないとなかな か臨床に用いることはできません。

\section{5. 自律神程摬能検查法としての 良学格の占める位而}

良導絡による皮府剌激療法は、とにかく皮庥 の機能というすのを重視し、これから出発して いるということはできると思います。そこで、 良導絡テストをどこの系列に含めるかと考えま すと、大ざっぱにいって、これはやはり皮底機 能を指標とする検査法のなかに入れてよいで しょう。良尊絡が東洋医学の特産である針众か らヒントを得て、これに科学のスポットをあて たものであるとはいえ、この基礎的研究の出発 点には皮庙䉓気抵抗湘定との関係を追及するこ とがあったのですから、筆者は中谷博士の良導 絡テスト、すなわち代表良導点の通電抵抗测定 法をこの系列に入れてみました。そして本法 は、他の方法と異なり極めて臨床に用いられゃ すいかたちでできていることが何んといって あ、すぐれております。

\section{6. われわれの行ってきた自律神略棤能検查法}

筆者らが良導絡テストを知る前に、これまで 臨床にまた研究に、主として行ってきた検查法 は、第 6 および第 7 表で※印をつけたるのであ ります。すなわち、(1起立させることを負荷と した血圧変動係数および脈博数変動係数を求め る方法。(2アドレナリンを注射して、血清 $\mathrm{K}$, $\mathrm{Ca}$ 值の変動を求める方法。(3)本川教授の考案 になる電気閃光値を测定する方法。(4)嗅神経を 
第 4 表

自律种老械能梌点法(1)

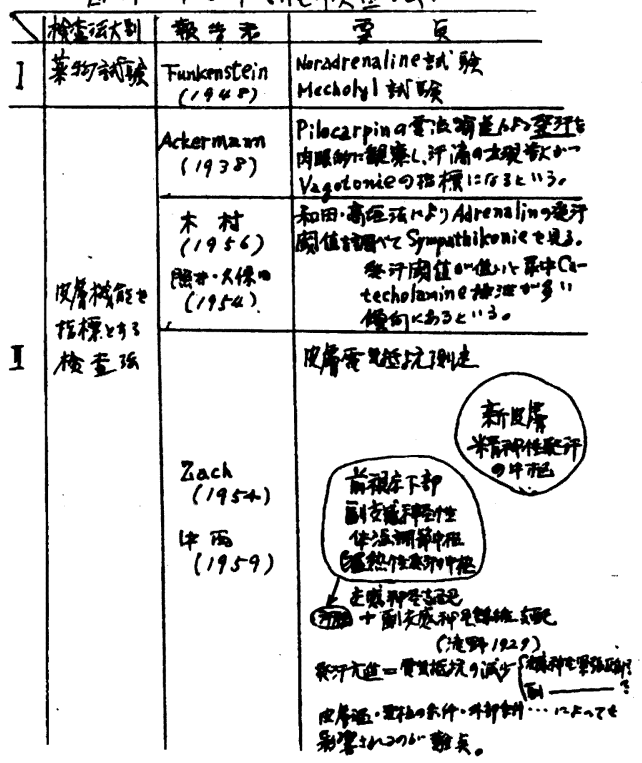

第 5 共

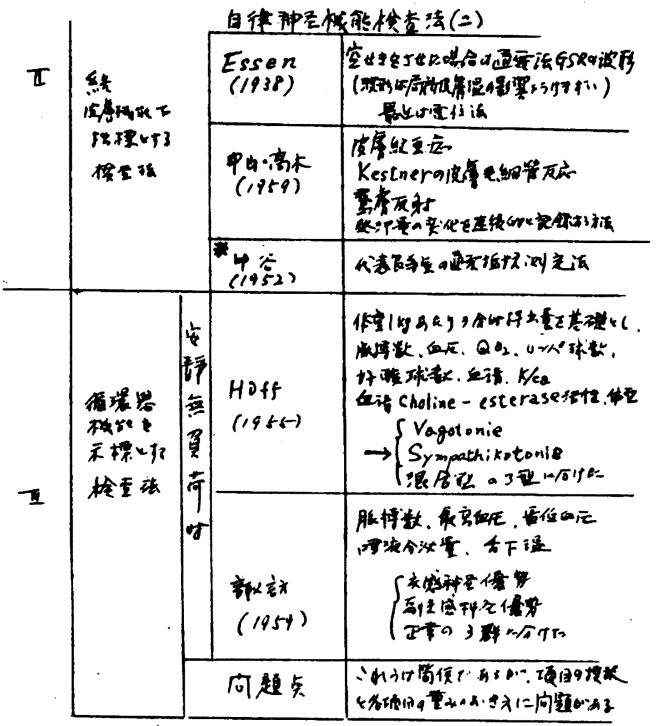

経偪的に電気刺激して直接算定法を用いて好塩 基球数の変動を求める方法。(5)アドレナリおよ びアセチルコリンを注射して血桾量の增減をみ ろ方法。などであります。しかる、これらの一 つの方法だけを用いて、自律神経系の全機能を

\section{第 6 关}

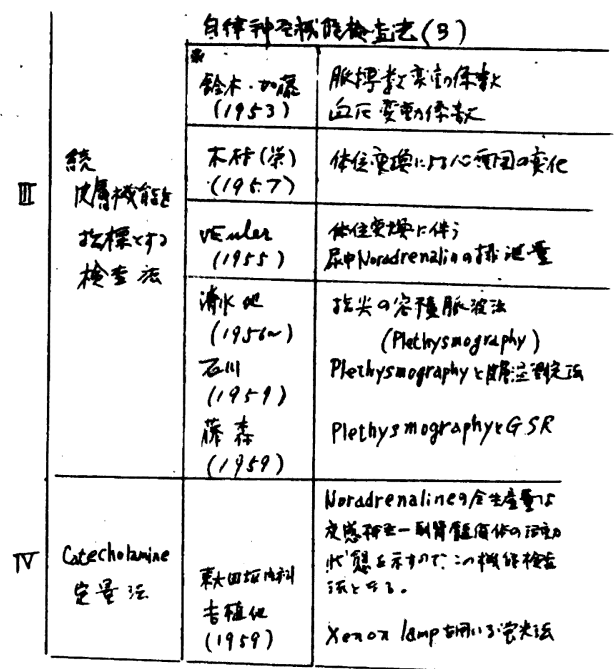

第7 表

自律种至珹的梌查法 (4)

\begin{tabular}{|c|c|c|c|}
\hline \multirow{5}{*}{ V } & \multirow{5}{*}{ 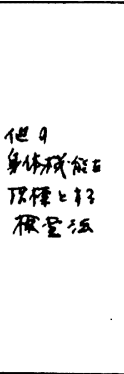 } & 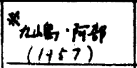 & 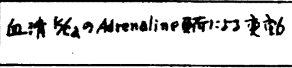 \\
\hline & & 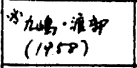 & 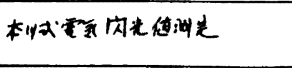 \\
\hline & & 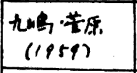 & 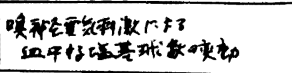 \\
\hline & & 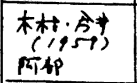 & 呼吸伿柏 \\
\hline & & $\begin{array}{l}H \circ f f \\
(1950)\end{array}$ & 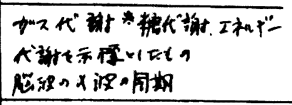 \\
\hline$n$ & & 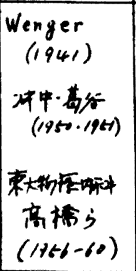 & 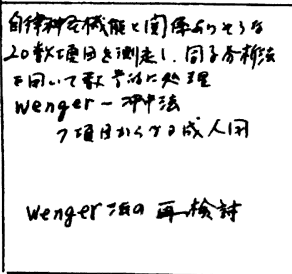 \\
\hline
\end{tabular}

判定する方法は現在ありまんので、これらの方 法を並列的におこなってその機能状態を知ろう としたのです。

第 2 および第 3 図には、婦人の機能性疾患に たいして、これらの検査法を並列的におこなっ 
空 2 这

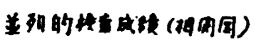
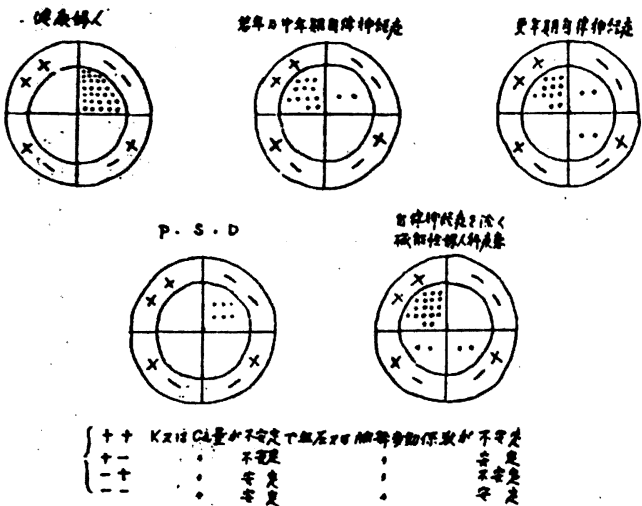

第3图 並列的㭲直成释(相因国)
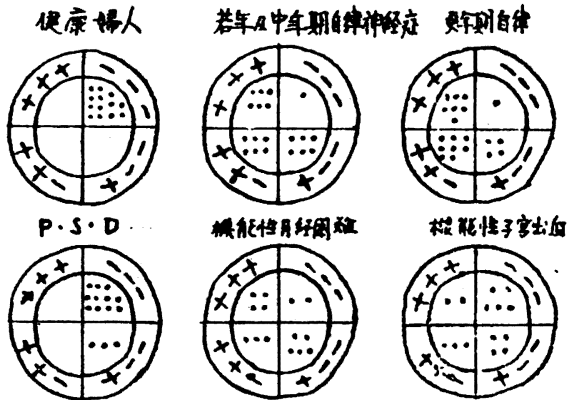

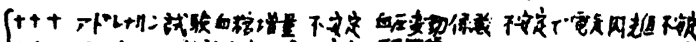

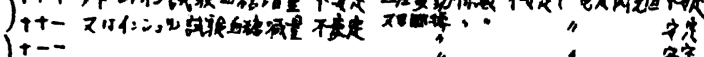
(1)-

た成績をしめしました。図の中の PSD とある のは、後でくわしく述べます婦人の精神身体症 （=PSD）の中の、心因性自律神経症でありま す。この成績からおわかりのように、自律神経 性疾患ではその自律神経機能は大部分が不安定 をしめすことを知ったのです。ところが、心因 性のものでは同じような症状を呈しているにる かかわらず、予想に反して、その自律神経機能 はむしろ健康婦人とおなじく安定なるのが多く 認められたのでした。このような結果を得たの は、自律神経機能検查法といわれるすのが、今 日、なお不完全であるためなのでしょうか。と すれば、何故自律神経性疾患では明らかに不安 定をしめするのがこんなに多いのでしょうか。 自律神経性疾患之心因性疾患とは発症機序が異 なるのでしょうか。筆者らは、その理解に苦し んだのであります。このような大問題をひかえ
て自律神経機能の状態をしめすといわれる良導 絡テストは、どういう解答を与えてくれるか。 早速実験にとりかかったのです。

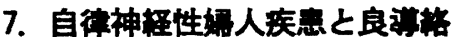

良導絡症候群という表をみますと、自律神経 症状として一括できる沢山の症状が出ておりま す。そこで先ず、機能性疾患のうちでも不正性 器出血とか外陰癔痒感などの症状を単独に呈し てくる疾患を実験対象とするよりは、これらの 症状を多く有している婦人の自律神経、とくに 間脳自律神経中枢の失調に基くところの自律神 経失調症をえらんで実験をおこなってみまし た。次に、実際に扱った症例のなかから、いく つかをえらんでその成績を述べてみましょう。

症例 (1)

22 歳の家婦で、流産後に肩こう、腰庯、頭捅、 めまい、疲労感などの症状がみられるようにな り、3 月月を経過しても、なお症状が続いてい るといって、わが外来を訪れたのです。本例は 第 8 表に示しましたように、H、が興逳を、F、

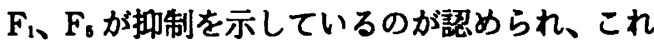
加ら得られる良導絡症候群は患者の訴える症状 とほぼ一致していました。この症例は男女混合 ホルモン療法 6 回で全治しました。

第8衰症例: 高.从自律种圣失袢症

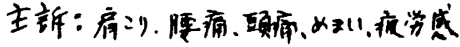

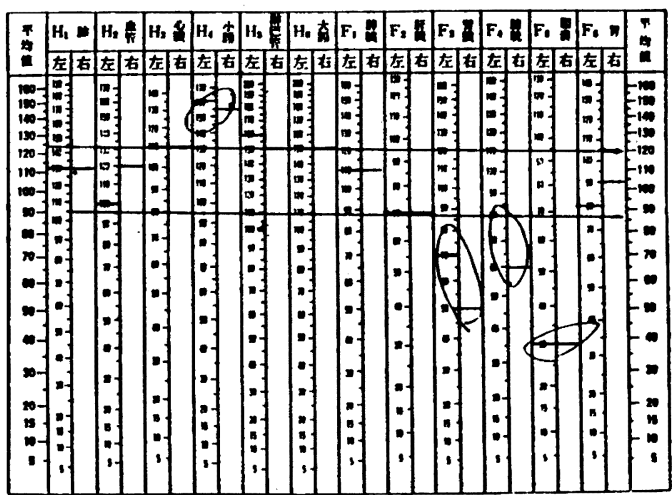

症例 (2)

27 歳の家婦。第 2 回目の分娭後、肩亡う、背 痛、腰痛、下腹痛、めまい、頭痛などの症状が あらわれたもので、この例は第 9 表のように、 $F_{1} 、 F_{2} 、 F_{4}$ が興古を、 $H_{1} 、 H_{4} 、 F_{3} 、 F_{6}$ が抑制を しめし、これる良導絡症候群と患者の症状とは 
一致しているのが認められました。

本例は $0.5 \%$ 塩酸プロカイン緩徐静注療法を

7 日間続けましたら、全治してしまいました。

症例 (3)

35 歳の家婦。胃下垂にて内科に入院中の患者 であり、頭痛、下腹部鈍痛、肩こり、めまい、 疲労感、のぼせなどの症状が消失せず、当科に 紹介されました。良導絡テストでは第 10 表の ように、 $\mathrm{H}_{3} 、 \mathrm{~F}_{1} 、 \mathrm{~F}_{4}$ が興奋を、Fs が抑制をしめ し、これから得られる良等絡症候群も患者の症 状とほぼ一致していました。本例は塩酸プロカ イン療法や男女混合ホルモン蟟法は無効でした が、クロールジアゼポキサイド療法 7 日間で症 状の大半が消失してしまいました。

\section{症例 (4)}

45 歳の更年期螮人で、頭重、めまい、腰痛、 しびれ感などの症状が半年前から出現し、当科 を訪れたものです。検查の成績は第 11 表のよ うに、F、 $F_{2} 、 F_{4}$ で興寉点を、 $F_{5}$ で抑制点を示 し、これから得られる症状も、患者の症状と大 体一致していました。本例はエストリオール内 服療法 7 日間で全治しました。

\section{8. 粠神身体医学之産婂人科}

最近、精神身体医学 (=PSM) というすのが、 さかんに唱えられるようになりました。しか し、PSM は何す目あたらしい特別な医学では ありません。昔から本邦です、心身一如という 言葉がありますが、PSM は近年、実験的にも衰 ずけられてきた心身相関の原理を導入して、従 来の肉体偏重の医学ではどうしても治療せしめ 得なかった疾患を、よりよく理解しようとする あのです。従って、実際には、ある疾病に対し てくわしく身体的都検查をおこなうと同じ程度 に、患者は病める人間であるから、患者の心理 的な面をる充分に検查し、情動（=感情=情緒 =エモーション）の面からす検討を加えるので あります。このような臨から浮彫りにされて きたのが精神身体症（=PSD）という疾患であ ります。とくに女性は男性に比して、自律神経 機能が不安定となり勝ちなだけてなく、より感 情的であります。そのため、女性には、解決で きない精神的葛藤や不安が起きますと、これが
主因となっていろいろな身体異常がおきて来る のです。産婦人科領城で PSD といわれる疾患 を第 4 図に示してみました。

PSD は心因性であろので心理的な考慮をし ない従来の治療では難治なるのであるために、 第 9 关

征例

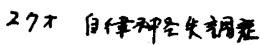

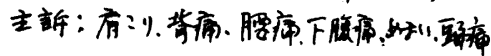

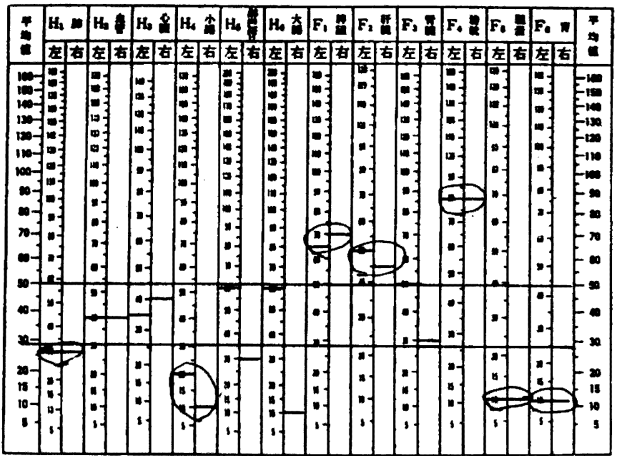

第10表在例: 35才自体种失调应

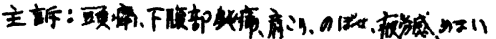

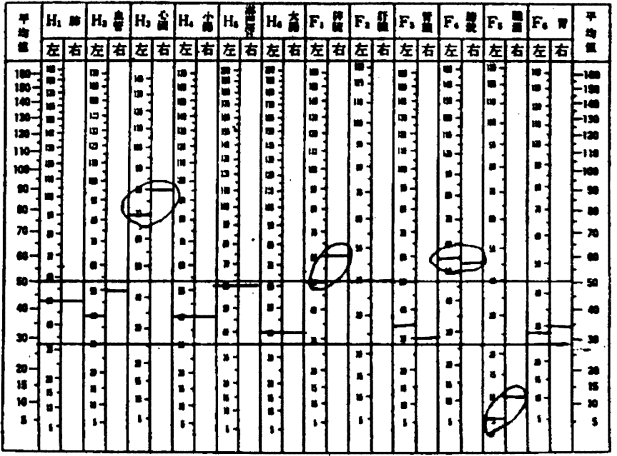

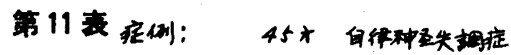

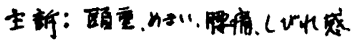

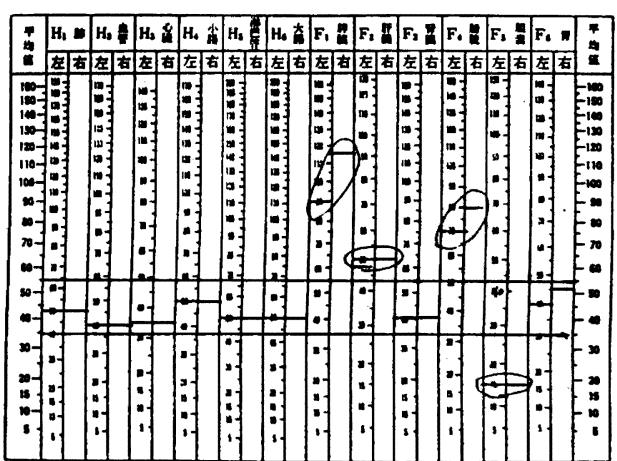




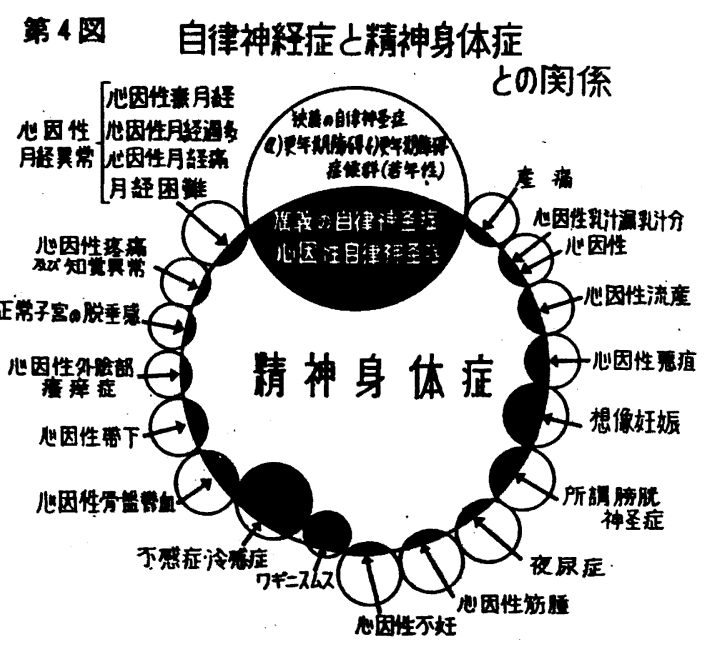

今日、各方面からとくに注目されているわけで す。

\section{9. 情功の乱れと自律神蛙・ \\ 内分汹機能との网保}

第 12 表に示しましたように、PSD は精神葛 藤などの情動障害によって自律神経緊張状烲が 慢性的に増大し、そのため局所的（平滑筋や血 管など）に、また全身性（内分汹腊器を介して） に機能失調をきたし、いろいろな身体症状を呈 するにいたると説明され、そしてそれはやがて 単なる機能的変化にとどまらず、器質的変化を あひきおこすすのであると説かれています。

しかしながら、情動の乱れはすべて本当に自 律神経系や内分泌系を介するすのかどうかこれ を証明しなければなりません。ところが婦人 PSD の場合、従来の自律神経機能検查法では 安定を示すすのが多く認められるのです。そこ で、この辺の一層の解明の必要にせまられ、こ の解決に良導絡テストが用いられたわけです。

\section{0. 姆人精神身体应と良刑格}

婦人の PSD は、前章にのべたように、「精神 葛藤などの情動障害が原因となってあらわれる 身体異常である」と定義されます。PSD と診断 されるものの種類には、いろいろなるのがあり ますので、その疾患名の上に心因性という形容 詞を冠して呼ぶことにしています。次に、婦人 の PSD の中では最す頻度の高い、心因性自律 神経症に良導絡テストを用いた成續を、いくつ
第 12 表

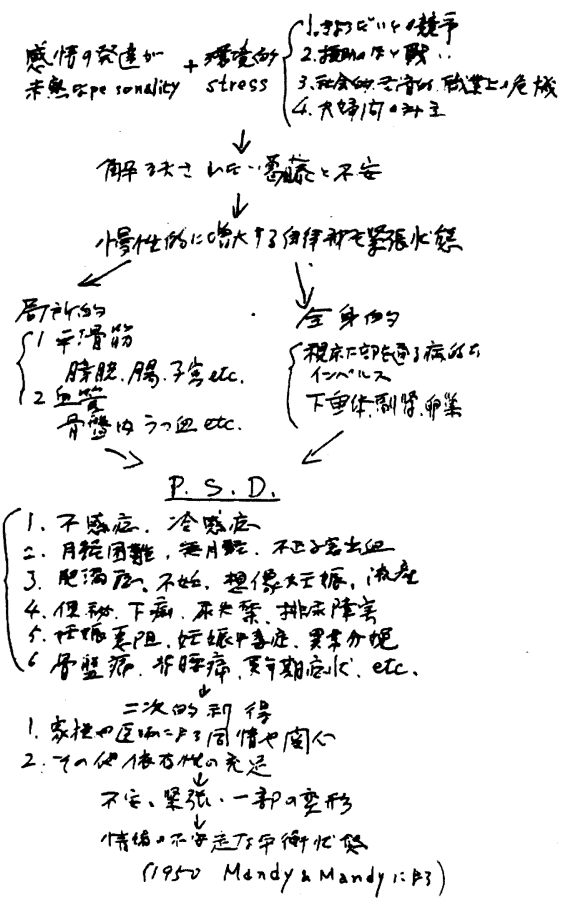

かの症例をあげながら述べてみたいと思いま す。

症例 (5)

32 歳の家婦で、人工中絶後に焦燥感、不眠、 のぼせ感、食思不振などの症状が出現し、治療 をうけてきたが好転せず、産婦人科医や内科医 を転々と変えたが治㥁せず、頑固な愁訴の故に 当科に紹介されてきました。われわれは、まず 自律神経失調症の診断の下に、外来で男女混合 ホルモン、次に塩酸プロカイン、次にクロール ジアぜポキサイドなどを投与しましたが、いず れも無効であって、かつ患者の愁訴のかげには 何か解決困難な感情的問題がひそんでいるよ う、みうけられ、そこで心因性のすのが疑われ たのです。この患者に、精神分析をおこないま した結果、患者には深刻な夫婦暮藤があり、夫 婦関係を拒否してきましたが、望まない妊娠を してしまい、人工中絶を受けなければならなく なりました。そしてこの手術後に本症状が出現 したのでした。本例にたいする成縝（13 表）は $\mathrm{H}_{6} 、 \mathrm{~F}_{2} 、 \mathrm{~F}_{6}$ でわずかに興奪をしめし、また $\mathrm{H}_{2}$ 、 $\mathrm{H}_{3} 、 \mathrm{H}_{4}$ および $\mathrm{F}_{5}$ でわずかに抑制をしめし、生 理的範囲からのずれが少いのが特徴でした。更 
にこれから求められた良導絡症候群と患者の訴 える症状とは、全然一致していなかったので す。本例はわれわれの絶食療法で全治してしま いました。

症例 (6)

32 歳の家婦で、 2 年前からの脑せ感、冷え症、 背痛、悪寒、疲労感、関節痛、動悸などの症状 に悩み、内科に入院して治療をうけて来ました が治甞せず、内科的には特に疾患が考えられ ず、あまりにも難治であるという理由で、当科 に紹介されたすのでした。われわれはPSDを 疑い、精神分析をおこないますと、患者は 3 年 前から道ならぬ恋愛におちいり、それによる性 倫理葛藤から本病を呈するようになったものと 診断することが出来ました。本例にたいする検 查成績 (第 14 表) は $\mathrm{H}_{6}$ の興据、 $\mathrm{H}_{4}$ および $\mathrm{F}_{5}$ の 抑制がみられたので、しかもこれから得られる 良導絡症候群之患者の訴える症状との間には大 きな差異が認められました。本例は心因性の診 断のもとに絶食療法を行いましたところ、的 に治㤲してしまいました。

症例 (7)

40 歳の家婦。3 年前から頭痛、疲労感、肩こ り、冷え症、記憶力不良、判断力不良、悪心、 しびれ感などを訴え、あらゆる薬物療法を受け てきましたが治叁せず、当科を訪ずれてきまし た。この患者の愁訴態度はきわめて頑固であ り、医師にたいしてる不信の態度をしめしてい ました。そこで PSDを疑い、精神分析をおこな いますと、患者はまだ結婚しておらず、某男性 の 2 号婦人をしていましが内心では性倫理暮藤 になやみ、そのため別れたいと思っているので すが、男性の強い反対と情実がからんで別れら れず、ここに本症を発していると診断されまし た。本例す第 15 表にしめしましたように、 $\mathrm{H}_{6}$ 、

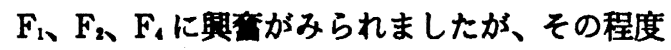
は著明でなく、またこれから得られた症状と患 者の実際の愁訴とは一致しない点が多く、その 成績は不鮮明でした。

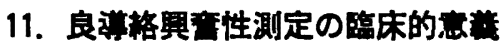

婦人の機能性疾患は、一応、器質的病变は除 外されておりますから、内腊の器官には変化

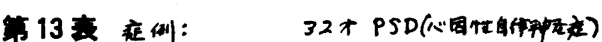

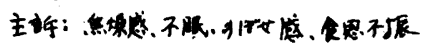

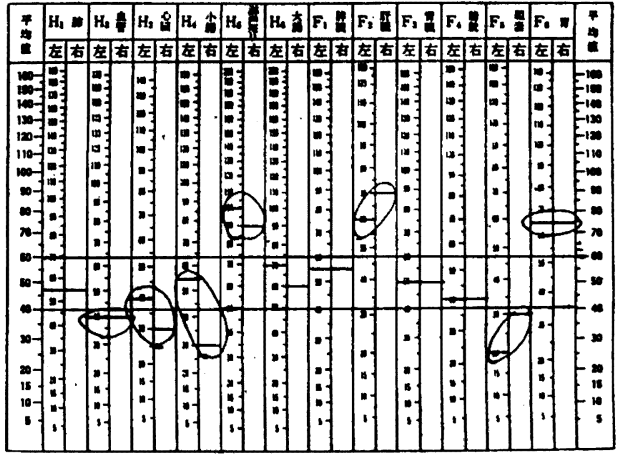

心四：夫嫜膤藤

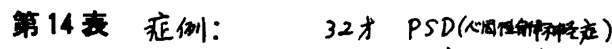

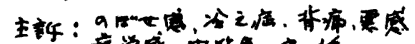

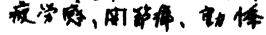

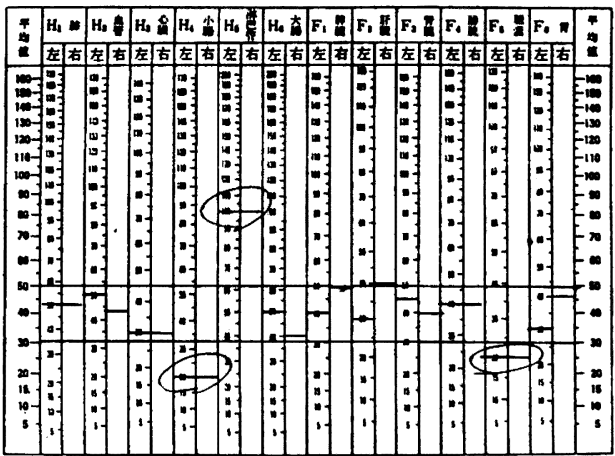

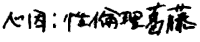

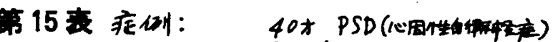

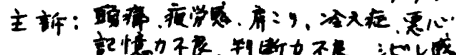

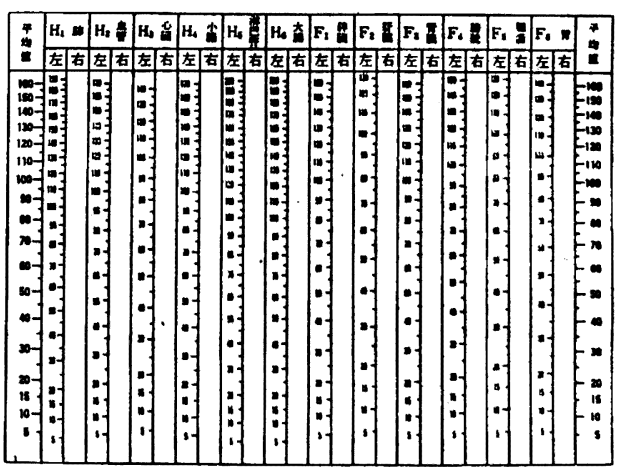

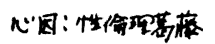


（器質的）がないるのであります。従ってこのよ うな疾患に良導絡テストをおこなう際は、これ によって特定の内胴に病変があることを立証す ろためにおこなうのではないのであります。す なわち、代表良導点 24 力所を测定することに よって得られた成績の全体の像から、その個体 の自律神経機能が安定であるか、或は不安定で あるかを判定したいわけであります。そこで、 まず筆者らは興奮または抑制をしめす值の、生 理的範囲からのすれに注目してみました。

1）生理的範囲からのずれ

(1) ずれの型分類

各代表良導点の通電抵抗值が生理的範囲から 上（=興套）または下（=抑制）の值をしめし たものを「ずれ」と表現すると、ずれの大きさ の大小とずれの頻度の多少から、おおよそ4つ の型に分類することが出来ました。

第 5 図はその 4 つの 第5図

型を模式化して図示し たものです。すなわ ち、I型は大きさが小 で、かつ頻度も少ない るの、ா型は大きさが 小であるが頻度の多い あの、正型は大きさは 大であるが、頻度の少 ないもの、そしてIV型 は大きさす大きく、頻 度す多いすのとしまし 生理的兴同以らのず

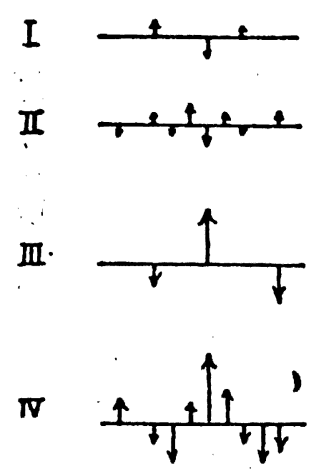
た。

（2）興鹪および抑制をしめするのの頻度 自律神経失調症 (=内分泌性) と PSD（ここで は心因性自律神経症）とにわけて、前者は 30 例、後者は 18 例について興奇および抑制をし めしたものの頻度（\%）を図示してみますと、 第 6 図のようになります。ただし、この場合、 ずれの大さは問題にしませんでした。ここで 両者の目立った相違点は、自律神経失調症では

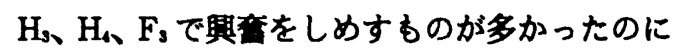
たいして、PSDではこれらの点で埛奋をしめ するのは少なく、むしろ抑制をしめするのが認 められたことです。しかるに、F。ではその反対 に前者では抑制、後者では興皨という結果をし
めしました。第 6 図

また、前者で

は $\mathrm{H}_{6}$ が 全

例、興皞をし

めしたのに、

後者では抑制

を示するのが

認められまし

た。反対に、

$\mathrm{H}_{6} 、 \mathrm{~F}_{2} 、 \mathrm{~F}$ 、で

は後者が全例

興第をしめし

たのに、前者

では抑制をし

めすものがあ

りました。両

者の共通点と

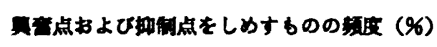

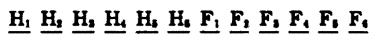

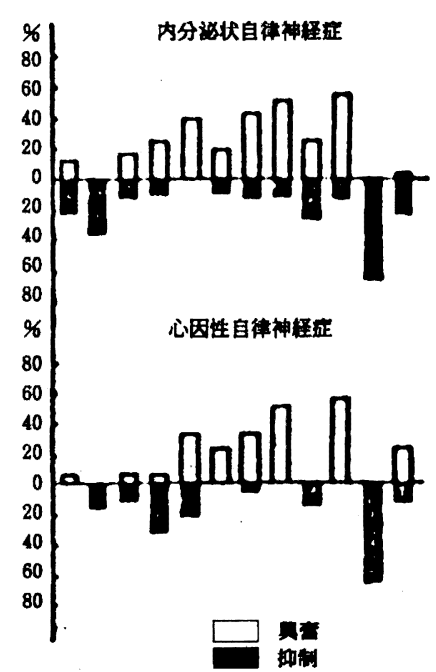

しては、 $\mathrm{H}_{2} 、 \mathrm{~F}_{5}$ で両者とも全例、抑制をしめし たことでした。

(3) ずれの頻度

次に、興傗と抑制とに分けず、それらを一括 して生理的範冊からずれたものとして、その頻 度を求めますと、第 7 図のようになります。白 は自律神経失調症、黒はPSDを表わしており ます。PSD では $\mathrm{H}_{1} 、 \mathrm{H}_{2}$ および $\mathrm{H}_{3} 、 F$, の四点が とくに自律神経失調症と比較して、ずれの頻度 が少なくなっていますが、 $\mathrm{H}_{1} 、 \mathrm{H}_{6} 、 \mathrm{~F}_{6}$ の3点で はPSDの方がその頻度が多くなっておりま ఫ。

（4）総括的成績

自律神経失調症と PSD とに分けて、次の 3 つの觀点から総括的に検討した成績をまとめま すと、第 16 表のようになります。その 1 は生理 的籍囲から 第7图

のずれの型

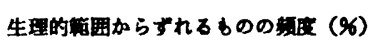

からみます

と、自律神

経失調症で

は 4 型が多

かったのに

たいして、

PSDでは

4 型はむし
$\underline{H_{1}} \underline{H_{2}} \underline{H_{2}} \underline{H}_{4} \underline{H}_{2} \underline{H}_{4} \underline{F}_{1} \underline{F}_{2} \underline{F}_{2} \underline{F}_{1} \underline{F}_{1} \underline{F}_{0}$

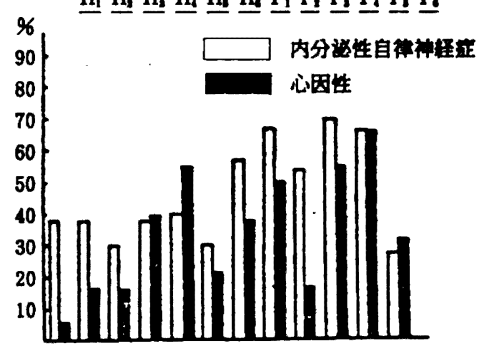




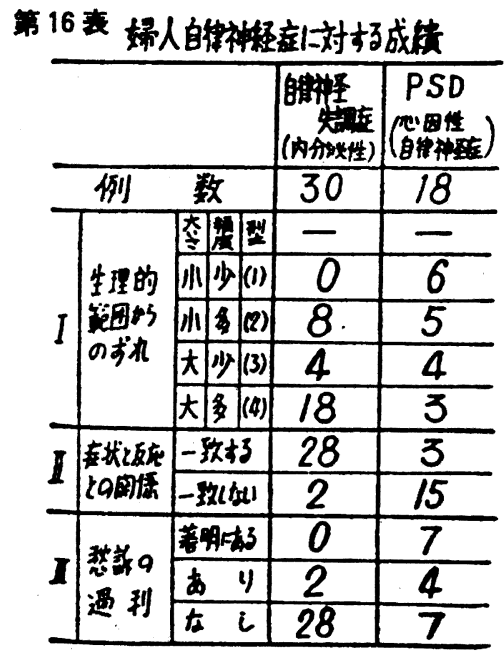

ろ少く、1〜3 型に多い傾向をしめしました。そ のII は患者の症状と良導絡症候群として挙げら れた症状（表中、反応と表現した）との関係で あります。これは自律神経失調症では両者の一 致するすのが多かったのにたいして PSDでは 一致しないあのが多かったのであります。その IIIは患者の愁訴数や愁訴㷫度と反応との関係で す。これは自律神経失調症では臨床的にす愁訴 態度は頑固でないばかりか、反応から評価する ことの出来了症状（不問診の）種類と実際、患 者が訴える症状の種類とは一致するすのが多 かったのにたいして、PSDでは「あっちす痛 い、こっちも痛い」とういった風に、本湘定法 による反応では全く現われない症状を多く訴え ており、いわゆる愁訴の過剩をしめすすのが少 なくなかったのであります。

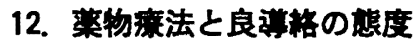

以上の成績から良導絡は個体の自律神経機能 の状態をしめするのであるということがわかっ たのであります。すちろん、自律神経機能と いったものはその性質上、複雑でかつ多元的な あのでありますから、この検査法だけで自律神 経の全機能を推測するのは、なお危険を伴うす のでありますが他の検查法ととすに用いれば、 婦人自律神経症の診断の補助的方法として用い て大いに意義があります。

また、自律神経 (失調) 症の萰物療法という あのは、間脳自律中枢にはたらき、その部の失

\section{第 17 表}

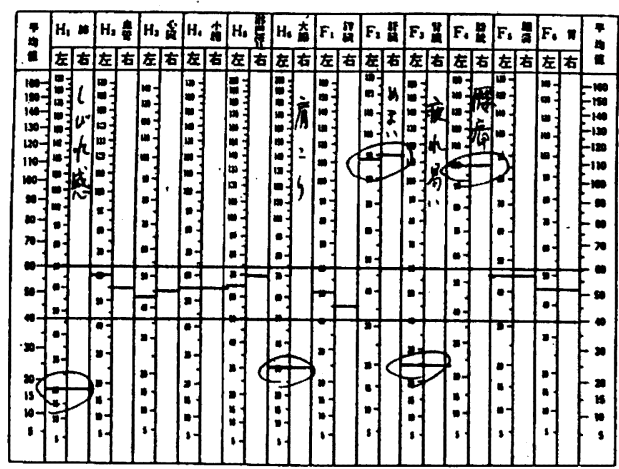

調を調整してやろうという目的でおこなうので す。ホルモン療法もそうであります。そこで、 この間の経過を良導絡テストで追いかければ、 治療の効果の判定という方面にも応用すること が出来ます。このような考えから以下の実験を おこないました。

そこで、良賏絡テストでこの経過を追及する ことにしました。その成結の1例を示してみま す。第 17 表はこの患者（28才の家婦自律神経 失調症) の投与前の成績ですが、生理的範囲か らのずれは大きく、これから得られる良導絡症 候群と患者の自覚的症状とはよく一致していま した。これに 投与しますと、症状む改善されず、テストでは 第 18 表のように、前回の成績（第 17 表）に比 して一層、生理的範囲からのずれが大きくなっ ているのを認めました。しかし、更にそれから 8 日間投与を続けていきますと、症状は劇的に 軽块し、テストでは第 19 表のように、今度は興 古点、抑制点ともに生理的範囲へ近づいている のが認められました。

生体の機能が病的状態から回復していくとき の過程において、このような一過性の反応はよ く臨床的に想められることですが、この良導絡 テストでこれほどまでに明確にキャッチできた のは素晴しいことです。皮䏀激療法を続けて こられた諸先生で、このような変化にお気づき の方すあると思います。従って、良導絡テスト は治療による効果判定法としてる大きな意義が あろわけです。 
管 18 :

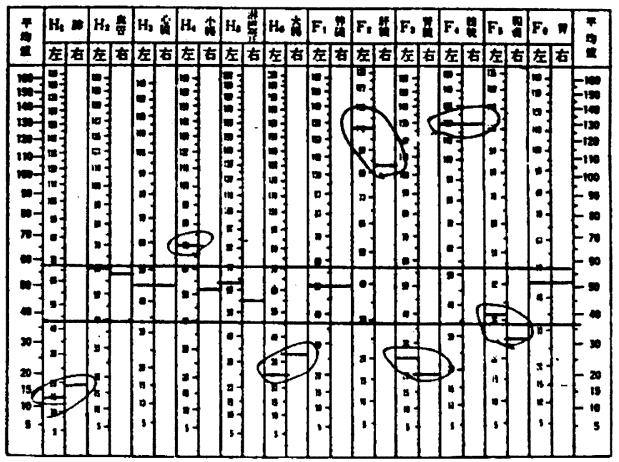

\section{第 19 表}

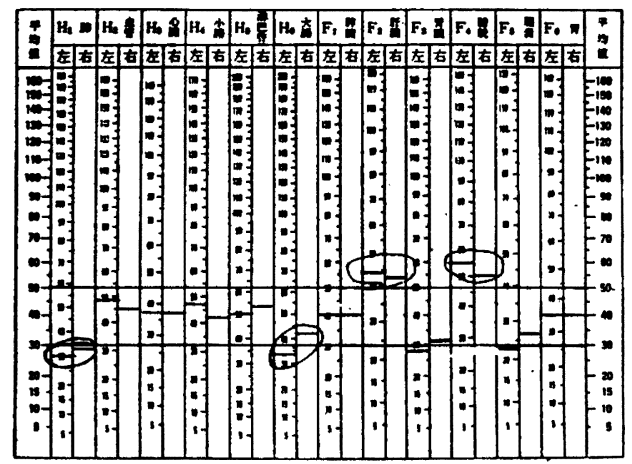

\section{3. 尾棏功瞆系球注射亡 HM,}

機能性婦人疾患のなかに婦人の腰痛症があり ます。これは婦人科外来を訪れる非妊婦の 15.6 \%、奼婦の $27 \%$ 多数に認められます。疾患別 に腰痛症の頻度を求めますと、実に子宮うう血 の $52.9 \%$ 、子宮後屈の $24.8 \%$ 、自律神経症の 19.7\%を占めています。筆者らは、このような 婦人の腰痛にたいしては、まず 3\%の塩酸プロ カイン $5 \mathrm{cc}$ を尾骨動脈系球に注射して良効果を あげてきました。従来、尾骨動脈系球は到動脈 糸球に類似の構造を有し、副交感神経系に属す ろものですから、この疾法は一つの自律神経調
整療法であると考えていたるのです。ところ か、この注射は良刑絡から申しますと、大略、 $\mathrm{HM}_{1}$ (長強) に一致しており、古来、本邦では度 慂にたいし、この点が注射点として注目されて いたことは面白いことであります。第 8 図は尾 骨動脈系球注射時の患者の姿勢を図示したるの です。毎日 1 回、5〜6回で効果があります。

\section{8 國}

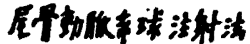

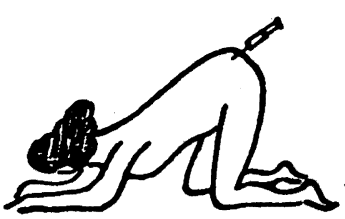

\section{4. むすひ}

以上、産婦人科における良迸絡の応用を、主 として自律神経機能との関連においてのべ、そ して最近、機能性婦人疾患の自律神経機能検查 法としてノイロメーターによる良䓕絡興营性湖 定法を用いた成䋶をのべました。しかし、良導 絡はこのような診断法としてまた検査法として 用いるというよりは、皮虔剌激潦法として用い られ、したがって従来、このような報告が多い ようです。産婦人科領域です、妊娠や分婏（と くに和痛分婏など)、不感症やその他の身体知 患に、これを治療法として用いてどうであった か、を期待されたことと思います。たしかにこ れらの問題す重要なことでありますが、まず第 一のステッブとして良刑絡の本来の性質という るのがどんなものであるか、についてより多く 興味を抱きましたので、今回は臨床的研究の目 的をこの辺においたわけであります。この小論 がいささかです皆さんの研究や診療のお役に立 てば、望外のよろこびであります。 